\title{
Competences for democratic culture: An empirical study of an intercultural citizenship project in language pedagogy
}

\author{
Leticia Yulita \\ University of East Anglia, UK
}

\begin{abstract}
This article reports on a pedagogical experiment in foreign language teaching in higher education. It analyses the democratic competences developed by Argentinian and UKbased students as they used Skype to design a leaflet that addressed a real world issue: the Argentinian military dictatorship and its manipulation of the 1978 Football World Cup. The data consists of students' discussions of this highly disturbing human rights issue. A first level of analysis focused on identifying evidence of democratic competences using the newly developed Council of Europe's conceptual model of Competences for Democratic Culture (2016). In a second level of analysis, the data was categorised within the framework of Article 2.2 of the United Nations Declaration on Human Rights Education and Training (2011). This research study provides an empirical test of these two frameworks in the field of language education, an aspect which has not been investigated before. It also contributes to our understanding of the potential of intercultural citizenship projects in achieving the goals of human rights education in foreign language teaching. Results indicate the development of substantial democratic competences defined in the Council of Europe's model.
\end{abstract}




\section{Keywords}

Language learning and teaching, intercultural, citizenship, human rights education, competences for democratic culture, Council of Europe, United Nations, Argentina, UK

\section{Corresponding author:}

Leticia Yulita, School of Politics, Philosophy, Language and Communication Studies, University of East Anglia, Norwich Research Park, Norwich, NR4 7TJ, UK.

Email: 1.yulita@uea.ac.uk

\section{Introduction}

It has long been argued that universities should nurture civically minded and engaged individuals with a sense of moral responsibility, respect for humanity, sensitivity, empathy and concern for social justice (Dewey, 1916; Taylor, 2005). White (2013, p. 112) asserts that the "purpose of the university should be grounded in the concept of citizenship rather than the promise of increased future earnings and research consultancy work'. Indeed, fostering civic literacy in society strengthens democracy and the view that higher education should prepare civic-minded graduates for the real world, both local and global, is the starting point of this study (Ehrlich, 2000; Kreber, 2016).

The field of intercultural education in foreign language pedagogy has been evolving steadily and rapidly over the past three decades, and has included in its purposes intercultural and citizenship competences with issues of human rights, social justice and equality (Osborn, 2006). Theoretical developments and research (Byram, 
2008, 2010, 2012, 2014a,b; Guilherme, 2002, 2007; Osler, 2012; Osler \& Starkey, 2005, 2015; Starkey, 2011) have recognised the unique contribution that foreign language teaching can make to citizenship education that promotes action at the transnational level. Hitherto, however, little attention has been paid to how this theory can be realised in the curriculum.

This article addresses this gap through the examination of democratic competences mobilised during an online project between language undergraduates in the Argentinian and British higher education sectors, which included taking action in the community. Citizenship education is of fundamental importance in higher education in both Argentina and the UK. However, teaching foreign languages to develop citizenship competences is a relatively new concept, and given that the pedagogical experiment described in this article took place in two different contexts - the European/British and the Latin American/Argentinian - it is important to consider their distinct ideological and educational discourses.

From the European perspective, language learning provides an opportunity to prepare learners as global citizens, capable of participating democratically in international arenas. For example, Guilherme $(2002,2007)$ advocates the development of an attitude in language learners which goes beyond national identities and appreciates the complexities and multiple identities of today's globalised world. In support of this view, Byram (2008, 2010, 2012, 2014a,b) introduces the notion of 'intercultural citizenship', which highlights the potential of language learning to give citizenship an international dimension whereby learners participate and act in the real world using their foreign languages.

These perspectives resonate with Osler and Starkey $(2005,2015)$, who bring principles of Human Rights Education (HRE) into the field of language learning. 
Another influence comes from the Council of Europe $(\mathrm{CoE})$ with the development of a Charter on Education for Democratic Citizenship and Human Rights Education (2010a). More recently, in 2016, the CoE published a new model of Competences for Democratic Culture (CDC) as a response to the urgent need to integrate democratic values and intercultural dialogue into curriculum design, pedagogy and assessment. There are however very few empirical studies testing these ideas in the field of foreign language teaching, except those that have been reported by Byram, Golubeva, Hui and Wagner (2017), Porto and Byram (2015), Porto (2014), Yulita and Porto (2017).

These European-based ideas have been picked up by the language teaching community in Latin America, frequently associated with learning the English language. A few reports of pedagogical initiatives testing Guilherme, Byram, Osler and Starkey's theories have been published. These date from 2003 with a seminar entitled 'Citizenship and language teaching' and a subsequent report (British Council, 2008) describing pedagogical proposals in English as a Foreign Language (EFL) contexts in three Latin American countries, one of them being Argentina (Hillyard, 2008). Another more recent British Council initiative known as 'Connecting Classrooms' has promoted exchange and collaboration between schools internationally, including between the UK and Argentina, to address global issues and develop teachers' awareness of the potential of global citizenship education in English language teaching practices. Further reports can be found in a Special Issue of the Argentinian Journal of Applied Linguistics edited by Porto (2015) with pedagogical proposals incorporating principles of intercultural citizenship education in English language classrooms from all education sectors.

The notion of citizenship in language teaching in Argentina also has a strong focus on building and strengthening national identity, and curricular innovations (Barboni, Beacon \& Porto, 2008; Beacon, Barboni, Porto \& Spoturno, 2013; Ministerio 
de Educación, 2011) incorporating principles of citizenship education in EFL primary and secondary sectors have been developed with this focus. Very few pedagogical innovations integrating language learning and citizenship have been reported (see, for example, Siderac \& Paez, 2013). One of the most influential initiatives in the primary and secondary school sectors has been developed by Ferradas (2008a, 2008b, 2009) under the banner of The Value of Values Campaign with EFL teaching materials focusing predominantly on national issues and set within the context of the Bicentennial of Argentina's freedom from colonial rule commemorated on 9 July 2016. There are no empirical research studies to date of these pedagogical proposals.

The purpose of this article is to demonstrate and analyse how foreign language teaching can address human rights issues in practice as part of intercultural citizenship education, and to relate this to two frameworks: the United Nations Declaration on Human Rights Education and Training (UNDHRET, 2011) and the new CDC model (CoE, 2016). The article continues with an overview of these two models as the underlying conceptual frameworks for this study. It then describes the participants and the pedagogical experiment. Following this, the article explains the method utilised in the analysis of the data, presents the results and discusses the findings of this study.

\section{Human Rights Education}

The research study was grounded in the definition of human rights education in Article 2.1 and the principles underpinning Article 2.2 of the UNDHRET, adopted by the General Assembly on 19 December 2011. Article 2.1 declares that:

\footnotetext{
Human rights education and training comprises all educational, training, information, awareness-raising and learning activities aimed at promoting universal respect for and observance of all human rights and fundamental freedoms and thus contributing, inter
} 


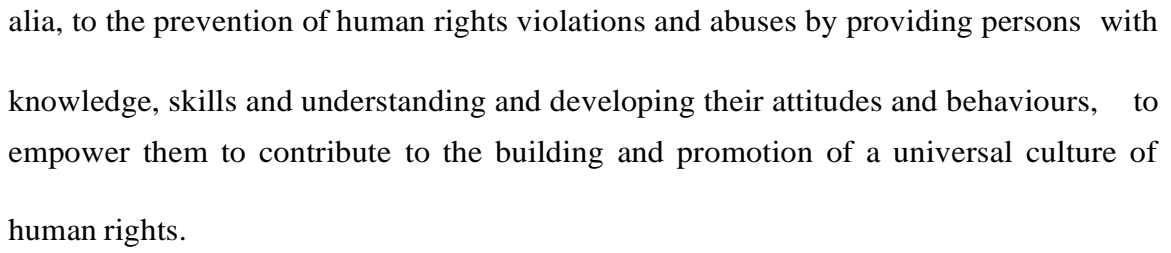

Article 2.2 states that human rights education and training encompasses:

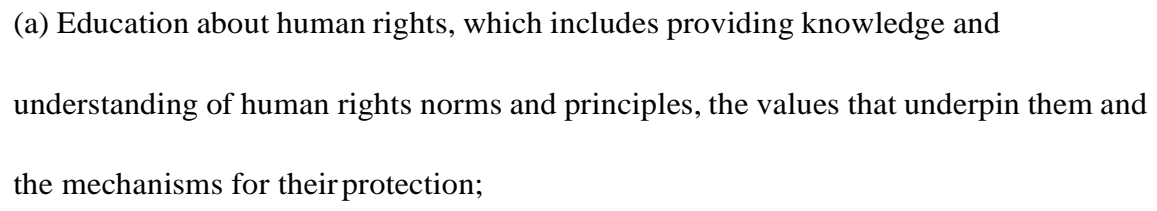

The essence of each of these three components is encapsulated in the use of the prepositions about, through and for. Education about human rights answers the question of what content should be covered; education through human rights answers the question of how it should be learnt and taught, whilst education for human rights is concerned with linking the theory (the content that is learnt) and the practice (the real world where the learning is to be applied). The three components are interconnected and complement each other. Importantly, they must all be present in HRE (Froman, 2015; Struthers, 2015).

The research study in this article was evaluated through the lens of UNDHRET. However, given that this tripartite framework of 'about, through and for' lacks sufficient detail for curriculum design, teaching and assessment (Struthers, 2015), the 
CDC model (CoE, 2016) was used to compensate for this limitation. This conceptual model consists of 20 competences -3 sets of values, 6 attitudes, 8 skills and 3 bodies of knowledge and critical understanding, as follows:

Values

- Valuing human dignity and human rights

- Valuing cultural diversity

- Valuing democracy, justice, fairness, equality and the rule of law

Attitudes

- Openness to cultural otherness and to other beliefs, world views and practices

- Respect

- Civic-mindedness

- Responsibility

- Self-efficacy

- Tolerance of ambiguity

Skills

- Autonomous learning skills

- Analytical and critical thinking skills

- Skills of listening and observing

- Empathy

- Flexibility and adaptability

- Linguistic, communicative and plurilingual skills

- Co-operation skills 
- Conflict-resolution skills

Knowledge and Critical Understanding

- Knowledge and critical understanding of the self

- Knowledge and critical understanding of language and communication

- Knowledge and critical understanding of the world: politics, law, human rights, culture, cultures, religions, history, media, economies, environment, sustainability

The model describes these competences in depth and states that their development facilitates living peacefully together as equals in culturally diverse democratic societies, a phrase borrowed from the CoE's White Paper (2010b). The term 'culture of democracy' rather than 'democracy' ( $\mathrm{CoE}, 2016$, p. 15) is used in the model to emphasise the fact that democratic institutions and laws can only work if grounded in a culture of democracy, which involves democratic competences, such as the aforementioned values, attitudes, skills, knowledge and critical understanding. In this article, the CDC model is used to evaluate the degree to which the competences have been learnt.

\section{Present study}

\section{Participants}

There were 99 participants for this study, of whom 23 were UK-based students (20 British, 1 Italian, 1 German and 1 Belgian) and 76 were Argentinian. Most of the research participants were female ( 89 compared to 10 male) in their late teens and early twenties. The cohorts consisted of groups of first year undergraduates learning Spanish 
at a British university and second year undergraduates learning English at an Argentinian university. The imbalance in number of students and different years of study across the two countries was due to differing student enrolment in the two participating universities and the teaching responsibilities of the teachers/researchers of this study. In terms of the Common European Framework of Reference for Languages (CoE, 2001), the participants' language proficiency ranged from B1 to B2 levels.

\section{Pedagogical experiment}

This pedagogical experiment was part of a larger project carried out for 16 weeks in 2013 and consisted of an online 5 week-long phase, where students communicated over Skype to design a leaflet for distribution to the public. Some of the pedagogical aims of this project have been evaluated in previous publications by Porto and Byram (2015), who found students' identification with a transnational community and levels of criticality that led them to action in the community, whilst Yulita and Porto (2017) examined to what extent a theory of intercultural citizenship had been implemented in language teaching. The appearance of the UNDHRET in 2011 and the CoE's CDC model in 2016 provide the opportunity to review the data from a new angle and at the same time consider one way in which these frameworks can be used.

The project focused on a dark period in the history of Argentina - a military dictatorship (1976-1983) which led to the disappearance (state-sanctioned murder) of thousands of people. The 1978 World Cup, held in Argentina, was used to mask the crimes and human rights abuses committed by the Military Junta to eradicate political dissent. Since the reintroduction of democracy in 1983, the people of Argentina together with organisations such as Madres de Plaza de Mayo ('The Mothers of Plaza de Mayo'), Abuelas de Plaza de Mayo ('The Grandmothers of Plaza de Mayo') and 
H.I.J.O.S (an acronym for 'Sons and Daughters for Identity and Justice Against Oblivion and Silence') have demanded an inquiry into the fate of victims of kidnapping and other human rights violations.

The choice of this particular topic was due to the fact that in 2013, when the project was completed, Argentina celebrated 30 years of democracy after the end of the dictatorship period in 1983. The Argentine and UK-based students researched the dictatorship and the World Cup in their foreign language lessons using texts in their foreign languages (Spanish in the UK and English in Argentina) and discussed this historical event of contemporary relevance in their respective classrooms. Students analysed the media representations of the dictatorship and the World Cup in print and other media of the time. They thought of other instances around the world in which sports events had been used to mask political dissent, human rights violations or conflict.

The pedagogical aims of the project were to raise awareness of media manipulation and censorship during international sporting events, and the learning outcomes for students were to foster the ability to critically analyse events of contemporary relevance, whilst developing democratic competences, such as respect, empathy and the value of justice. In terms of language learning, the project was intended to develop linguistic competences so that students can act as, and become more effective intercultural mediators (Byram, 1997; Byram \& Zarate, 1994; CoE, 2001).

Intercultural mediation involves the ability to analyse, interpret, explain and compare cultural phenomena using languages as tools for understanding, communicating and mediating between different interpretations and perspectives. In groups of mixed nationalities, students then collaboratively designed a leaflet in English 
and Spanish to raise awareness of the human rights violations that happened during the World Cup in 1978 (examples of these leaflets can be found in Yulita \& Porto, 2017). In this article the focus is on empirical evidence for democratic competences mobilised as the students managed the task of creating the leaflet over Skype.

The citizenship dimension of the project involved students designing and implementing a civic action in their local communities (i.e. actions in the real world based on their learning) with the aim of raising awareness of human rights issues locally and globally and creating change through the dissemination of the leaflet (details of civic actions can be found in Porto \& Byram, 2015).

\section{Data analysis}

The main source of evidence concentrated on conversational data, which involved Skype conversations transcribed verbatim, i.e. without editing in terms of grammatical, lexical, syntactical or any other inaccuracies. In this article, data are presented in the language that was used by the students, without corrections and with the teacher/researcher's translation into English in cases where Spanish was used. Groups of four or five students met over Skype to design the leaflet, each group consisting of one UK-based student and either three or four Argentinian students.

These data were collected in 2013 from the project as previously described, and analysed following the guidelines and procedures for content analysis in Corbin and Strauss (2014), Hatch (2002) and Cohen, Manion and Morrison (2011). Based on the CDC conceptual model, I formulated the main research question in this study What democratic competences did the students mobilise during the design of the leaflet?. A first level of analysis consisted of coding the data by separating it into pieces corresponding to natural breaks and assigning a code that corresponded to a competence 
from the CDC model. Using the model was helpful in terms of following an interpretative systematic method, and once the emerging themes were coded, a second level of analysis consisted in categorising them within the framework of the UNDHRET. This process led to the formulation of three operational questions (a) what did the students learn?; (b) how did the students learn?; and (c) in what ways were the students oriented towards action?. These sub-questions corresponded to the tripartite UNDHRET framework and aimed at translating and operationalising the more general research question into more specific, concrete ones.

Confidentiality and ethical issues were addressed. Sufficient information describing the goals and procedures and the method employed and an assurance that confidentiality and anonymity would be maintained were provided. All participants were informed that although quotes from the data collected would be used for analysis,

pseudonyms would be employed in an attempt to reduce the possibility of being recognisable to other researchers or readers. Students then signed informed consent forms to allow disclosure of their productions. How the UNDHRET and the CDC can be seen to work in practice is demonstrated in the next part of this article, through the presentation of the findings in the answer to the three operational research questions in order to address the more significant general research question posited in this study.

\section{Results}

The results are presented under the three components of the UNDHRET (1) education about human rights; (2) education through human rights; and (3) education for human rights. An analysis of the democratic competences, as conceptualised within the CDC model, developed by the learners during the design of the leaflet, is provided in each 
category. The main democratic competences developed by the learners will be highlighted in italics in the three sub-sections and discussion that follow.

\section{Education about human rights}

Here I present empirical evidence to answer the first operational research question what did the students learn? during their Skype conversations, with particular reference to the cognitive aspect of their learning in terms of what kind of knowledge and values they developed. For their leaflet design, both Argentinian and UK-based students gained knowledge and critical understanding of the world, and in particular, of the "processes through which the mass media select, interpret and edit information before transmitting it for public consumption' (CoE, 2016, p. 55). A number of photographs for the leaflets were considered and media censorship was identified as one of the 'contemporary threats to democracy' (CoE, 2016, p. 52). For example, some Argentinian students deliberated upon the fact that certain pictures shown around the world were not circulated in Argentina for fear of people being made to disappear. One Argentine student explained:

\footnotetext{
SILVANA: los medios argentinos no podían controlar lo que la prensa dijera en el resto del mundo [Argentine media could not control what the press said in the rest of the world].
}

In their scrutiny of images from other parts in the world revealing the human rights violations in Argentina, another Argentine student commented that:

\footnotetext{
MARÍA: está bueno ver que en otros países se mostraba la realidad, lo que estaba pasando acá, y que acá en nuestro país, eso no se podía ver' [it is good to see that other
} 
countries were showing the reality, what was happening here, and what here in our country we could not see].

In the design of their leaflet, some British students chose the 1989 Hillsborough Stadium Disaster in the UK as an example of a violation of human rights. This incident, regarded as one of the world's worst football disasters, was primarily caused by the police admitting more supporters into the stadium than the safe capacity, which resulted in a human crush causing 96 deaths and hundreds of injuries (Hillsborough, 2012). In their discussions, John, a British student, spoke about the police errors and explained how 'Margaret Thatcher's government hid crucial documents to blame Liverpool hooligans' so that she could lead people into believing that 'they were responsible for the tragedy'.

As the project teams shared relevant and useful information that they had found in the press, they developed essential democratic competences specified in the CDC model - knowledge and critical understanding of history and the value of justice (CoE, 2016, p. 54). For example, some British students critically examined the allegation that Thatcher's government selected and constructed facts that became the evidence of the narrative of the time leading to social injustice. As their discussions progressed, students explained how past injustices can be dealt with peacefully in the present. The Hillsborough Justice Campaign shop and a plaque with the names of those who died in the stadium were mentioned as illustrations of how more recent British governments have promoted a democratic culture in their society.

Learners examined and applied memories of the past to the present in the hope that the future may be transformed and they explicitly highlighted the importance of remembering the past as a way to prevent similar situations in the future. In this respect, the $\mathrm{CDC}$ model specifies that 'understanding and interpreting the past in the 
light of the present with a view to the future' (CoE, 2016, p. 54) is an important competence for a democratic culture. For example, Florencia, an Argentine student, discussed the role for formal education in this endeavour by saying 'I think by teaching children ... schools [...] It makes everybody aware'.

The role of education was valued as a way to promote a democratic culture, which for them meant teaching children about human rights, raising awareness in society and implementing topics such as this one in the school curriculum. Remembering the past through education in order to raise awareness in the local community in the present can be seen as a way of 'understanding the relevance of the past to concerns and issues in the contemporary world' (CoE, 2016, p. 54).

As the students described the savage violence and brutal cruelty as the backdrop of the 1978 World Cup, they recognised and valued fundamental freedoms such as freedom of expression. For example, Jeremías, an Argentine student, exclaimed:

\footnotetext{
JEREMÍAS: ...the main thing we were taught when we were little was that we don't have to be afraid of expressing what we think ... that is something that we learn in our generation.
}

These are all democratic competences in the CDC model, and from this perspective, the design of the leaflet provided the students with the forum for the examination of democratic peaceful ways of dealing with past injustices.

\section{Education through human rights}

Here I present empirical data to answer the second operational research question how did the students learn? as I searched for evidence of methods that developed skills for active citizenship. Co-operation skills, defined in the CDC model as 'skills that are 
required to participate successfully with others on shared activities, tasks and ventures' (CoE, 2016, p. 49) were widespread in the data. The design of the leaflet provided the platform for the students to express their views and opinions and to help each other with their work. This can be gleaned in the frequent occurrences of questions and offers of help such as:

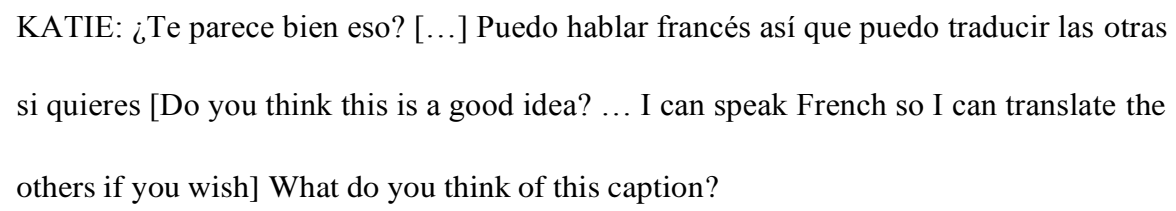

Project teams identified and set goals, for example Daniela said 'we have to agree what we are going to add in each space' in the creation of their leaflet, and discussed ways in which the information could be displayed and translated.

Students used their linguistic, communicative and plurilingual skills for the benefit of their groups by translating picture captions from and into different languages in their attempt to create a leaflet that showed the world's perspective on the 1978 World Cup. For example, one project team explored the possibility of using images from Brazil, France and Holland to show how the sporting event was viewed in these countries. Given that the captions in these images were written in other languages, the students discussed possible translations into English and Spanish and shared linguistic expertise amongst the group members.

The online phase of the project allowed for the development of the students' autonomous learning skills, defined in the CDC model as 'skills that individuals require to pursue, organise and evaluate their own learning, in accordance with their own needs, in a self-directed and self-regulated manner, without being prompted by others' (CoE, 2016, p. 44). These skills permeated the data as the students collaboratively made 
decisions about the sporting event to juxtapose with the 1978 World Cup, the wording and the images for their leaflets. For instance, one project team explored the possibility of selecting the 2008 Olympic Games in Beijing for their leaflet in order to address the allegation that China attempted to conceal human rights violations by not allowing open media access. Students compared the media coverage in Argentina and China during both sporting events to highlight media manipulation by governments involved in the violation of human rights and they then made decisions about the type of information that they needed to research.

Students identified gaps in their knowledge and understanding, as can be gleaned from these data:

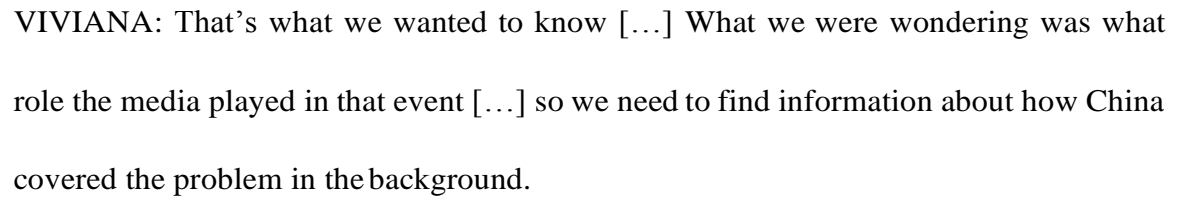

They also located possible sources of information from their interactions with others in the group:

\footnotetext{
FRANK: Can you send me that list? [...] Maybe you can find more or less the same things for Beijing.
}

These skills are deemed to be important for a culture of democracy because 'they enable individuals to learn for themselves about, and how to deal with, political, civic and cultural issues using multiple and diverse sources both far and near' (CoE, 2016, p. 44). Similarly, students showed flexibility and adaptability to arrange to meet over Skype given the time difference and their own personal commitments. 
Students' active listening permeated the data, as can be perceived in Griselda's reformulation of a message being conveyed to her 'es decir, tomaron todo el control' [that is to say, they took all the control]) and Ben's assurances of having understood 'OK, yeah, I understand, honestly'. When there were language difficulties or misunderstandings, students frequently facilitated comprehension by inferencing, verifying, understanding and assisting comprehension. Students also helped each other by providing lexical items as and when needed to aid both expression and comprehension of messages:

\author{
FERNANDA: The editor was fired. And he had to .... se tuvo que exiliar ... exilio .... \\ how do you call it? \\ LAURA: There was a sports newspaper that was called El Gráfico ... El Gráfico was \\ also ‘intervenido’? ¿Cómo se dice ‘intervenido’? [How do you say ‘intervenido’?]
}

Under linguistic, communicative and plurilingual skills, the CDC model refers to 'the ability to manage breakdowns in communication, for example by requesting repetitions or reformulations from others, or providing restatements, revisions or simplifications of one's own misunderstood communications' (CoE, 2016, p. 49), and this is precisely what we see here.

\title{
3 Education for human rights
}

Here I present empirical data to answer the third operational research question in what ways were the students oriented towards action? I searched for evidence of competences which were most likely to foster the application of human rights knowledge to practice and to encourage learners to act in the face of injustices. All of 
the students had in common that they were temporally removed from the events of the human rights violations of the Argentinian military dictatorship. Despite this, the experiences of the Argentinian and the UK-based students were substantially dissimilar. The latter group were also geographically removed from the events and less likely to have heard about them, unlike their Argentine project partners who had learnt about them through family, friends, the media and education.

As a result of this, the emotional involvement was significantly different. This can be evidenced in the fact that some Argentinian students highlighted the fact that social injustice was still present in their society. For example, Emilia and Victoria exclaimed 'it isn't over'; 'it happens every day'; 'this hasn't finished', whilst others acknowledged a lack of action to stand up for humanity, as can be gleaned from Eduardo's comments 'nobody does anything'; 'we're still repressed'. Argentinian students became aware of the importance to discuss and act upon human rights issues.

Some UK-based students placed the disappearances, tortures and killings in Argentina in a global context and held the world accountable for these crimes against humanity. These students highlighted that the world, despite knowing, kept passive:

\footnotetext{
BRIONY: the rest of the world did still know [...] however, despite the fact that they did still know, they didn't want to say.
}

The allegation that the rest of the world knew but 'didn't want to say' is regarded as blameworthy and as bad as the Argentine media not transmitting 'what was really happening', as per the words of one of the Argentine students. Regardless of their nationalities, some of the students adopted a thoughtful approach towards the actions of the people in their respective societies during this period in history and reflected upon the consequences of remaining passive by not standing up for humanity. In this respect, 
the CDC model identifies moral responsibility as a democratic attitude to be fostered, which all students alike thought it important to take in their hands on behalf of those who lacked the courage to take a principled stance at the time. Certain project teams judged that this was morally wrong and decided to take action themselves by highlighting this issue in their leaflet.

Developing an attitude of civic-mindedness, in the sense of developing 'feelings of concern and care' (CoE, 2016, p. 41) can be interpreted as a way to promote orientation towards action. Civic-mindedness is linked to the skill of empathy. The CDC model defines empathy as the 'ability to step outside one's own psychological frame of reference (i.e. to decentre from one's own perspective) and the ability to imaginatively apprehend and understand the psychological frame of reference and perspective of another person' (CoE, 2016, p. 47).

This civic-minded attitude of being able to empathise with others can be understood as an indicator that can trigger civic action. Findings in this study demonstrate the students' ability to apprehend and understand the feelings, emotions, needs and perspectives of the victims. However, the data evidences challenges posed on the 'mind' when students tried to 'understand' the reasons for the brutalities and atrocities committed during this dark period in history. This type of understanding, referred to in the CDC model as cognitive self-awareness (CoE, 2016, p. 51), was shared by both UK-based and Argentinian students alike. For example, students expressed great difficulty in understanding the motives underlying some of the political ideas, stances and decisions of the time, as can be gleaned from this data:

SANTIAGO: I've never understood why all this started ... KAREN: You can't really understand ... 


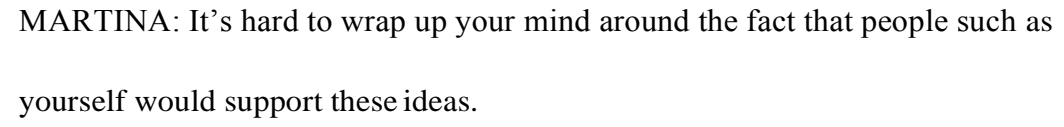

In this regard, the CDC model states that 'self-awareness and self-understanding are vital for participating effectively and appropriately in a culture of democracy' (CoE, 2016, p. 51) and identifies emotional self-awareness of one's perspective on the world as an essential democratic competence.

Outrage was a key emotion in the data. For example, Marcela, an Argentine student sought a solidarity bond from Emma, her UK-based project partner by encouraging her to place herself in the shoes of the disappeared. Marcela asked 'How would you have felt if you, your family and friends had lived during those times of torture and disappearances?'. In her reply, Emma referred to feelings of anger and fear 'I would have felt very angry with the government, but at the same time I think I would have felt fearful of what was going on around me'. Oxfam (1997, p.1) views learners motivated to take action when being 'outraged by social injustice', an emotion that permeated the data in this study as students expressed their belief that 'every individual human is entitled to fundamental freedoms and ought to be treated accordingly' (CoE, 2016, p. 36) and that 'social justice ought to prevail' (CoE, 2016, p. 38).

\section{Discussion}

\section{Analysing competences developed during the project}

As indicated earlier, it is increasingly recognised that language teaching and learning should promote awareness of issues relating to HRE (Osborn, 2006; Osler \& Starkey, 2005; Yulita \& Porto, 2017). With this in mind, here I discuss how successful the collaborative task of the leaflet design has been in achieving the goals of HRE through the lens of Article 2.2 of the UNDHRET and the CDC model. From a pedagogical point 
of view, the CDC model served as a basis for evaluating the teaching, in particular the learning objectives of the leaflet design task. Not all the competences in the CDC were realised in the data, and those that were, were activated, mobilised and orchestrated as a cluster of competences, for as the model states, 'in real-life situations, competences are rarely mobilised and used individually' (CoE, 2016, p. 24).

The first component 'education about human rights' of Article 2.2 of the UNDHRET incorporates the dimension of knowledge and values with human rightsrelated content. Specifically in this study, the values manifested by the students during the design of the leaflet were expressed in the ways they applied, understood, related, explained and analysed knowledge. The CDC model makes a distinction between knowledge and critical understanding. Knowledge is described as the body of information that is possessed by a person' (CoE, 2016, p.51), whereas critical understanding involves comprehending, appreciating, evaluating, interpreting, and reflecting on that knowledge.

The term 'critical' in the CDC model is important. Porto and Byram (2015) analysed data from this same project, drawing on Barnett (1997), and found evidence of students' development of critical skills, which led to engagement and action in their community. The link between critical understanding of the world and the analytical and critical thinking skills that the students applied in their Skype discussions is captured in the arguments they developed whilst selecting images for their leaflets. Learning to think critically is at the core of the CDC model as a way to eradicate extremism and to promote a culture of democracy. Learners shared knowledge and developed an understanding of 'how media images are produced, and of the various possible motives, intentions and purposes of those who create and reproduce them' (CoE, 2016, p. 55). 
The second component 'education through human rights' of Article 2.2 of the UNDHRET comprises learning and teaching in a way that respects the rights of educators and learners. In this study, the pedagogical approach allowed for participation, communication, engagement and interaction, where knowledge and critical understanding were democratised amongst students. The topic and the task were pre-determined, but not the specifics of the human rights-related content to be explored. Students had the freedom to express their own opinions through working with and listening to others, and offering help when needed. Similarly, they collaborated with each other to aid comprehension through a variety of strategies, such as simplifications, confirmations, reformulations and repetitions, and when gaps in language skills were noticed, help was provided by project partners. All these practices came from the students themselves, made possible and facilitated by the teachers/researchers.

The flexibility of this pedagogical strategy allowed for the collaborative creation of knowledge grounded in the students' own experiences and interests. Neither the teachers nor the curriculum dictated the content, which emerged from the explorative and investigative dialogue the students engaged in. Students examined their own lives and those of others, looked critically at their own reality and benefitted from informal learning opportunities. These participatory, student-centred pedagogical practices are at the heart of democratic education (Dewey, 1916) and grounded in human rights principles.

The third component 'education for human rights' of Article 2.2 of the UNDHRET is oriented towards action and aims to foster an attitude of civicmindedness, defined in the CDC model as an attitude 'towards a community or social group [...] that is larger than one's immediate circle of family and friends and to which one feels a sense of belonging [...] and identification' (CoE, 2016, p. 41). Civic- 
mindedness is also understood in the CDC model as 'an interest in, and attentiveness towards, the affairs and concerns of the community', 'a sense of solidarity with other people in the community' and 'a sense of civic duty' (CoE, 2016, p. 41).

Specifically, education for human rights comprises the development of a sense of moral responsibility within students so that they feel compelled to act in the real world. It aims to develop awareness of human rights issues and to provoke students to take civic or political action to protect their own rights and those of others. For this to happen, it is necessary for students to develop a sense of 'we-ness' (Kemmis, 1990), which the design of the leaflet allowed for. This togetherness was evidenced in their willingness to co-operate by volunteering to take on tasks, such as translating picture captions and gathering information for the benefit of the transnational group, to which they temporarily had a sense of belonging. It was also demonstrated by skills like empathy, affective perspective-taking, cognitive and emotional self-awareness. That this then led to 'action in the community' in the spirit of citizenship education has been explored elsewhere (Porto \& Byram, 2015; Yulita \& Porto, 2017).

\section{Using the empirical data to test the model}

Considering the issue of whether the CDC model can account for all the empirical data, the analysis suggests a need to develop nuances in relation to fostering peace as a democratic value, particularly when topics relating to human rights violations are discussed. Research has argued that past trauma may be transmitted intergenerationally (Bowers \& Yehuda, 2016; Barkan, 2000; Leen-Feldner, Feldner, Knapp, Bunaciu, Blumenthal \& Amstadter, 2013; Yehuda, Daskalakis, Bierer, Bader, Klengel, Holsboer $\&$ Binder, 2016). This growing area of research suggests that children of traumatised individuals exposed to conflict may be a high-risk group of developing anger, 
depression, aggression, revenge and hostility. Therefore, a potentially greater number of people may require competences that may assist in the healing of trauma after violence. Empirical studies (see for example Enright, Rhody, Litts \& Klatt, 2014; Shechtman, Wade \& Khoury, 2009) have found that forgiveness education can be one of the ways in which emotions relating to (post) trauma can be reduced and inner peace promoted. These studies indicate that forgiveness can lead to improved psychological well-being, better academic performance and reduced behavioural problems. Indeed, the CDC model outlines competences that tangentially address the value of peace and forgiveness, without explicitly including it as a democratic value. The inclusion of peace as a value may prove a useful addition to the model to encourage practitioners to address (post) trauma through education, thus mitigating against the perpetuation of violence.

\section{Conclusion}

This article reports on a pedagogical experiment that aimed to realise the two participating universities' commitment to preparing learners as informed and engaged global citizens, giving that commitment a particular international dimension distinctive to the discipline of language teaching. The results in this study demonstrate that the learners developed a set of democratic competences. The underlying intention of the task of designing a leaflet was to nurture an attitude that would encourage them to take action in their community, and students did indeed display a wide range of competences of fundamental importance for the development of civic-mindedness. This study, completed from an insider-practitioner perspective within the context of the learning and teaching of foreign languages in higher education, examined data through the lens

of Article 2.2 of the UNDHRET and CDC model and at the same time served as a 
proving ground for the CDC model. The research demonstrates that the online phase of the project opened up a space to develop democratic competences as learners addressed the profound sense of injustice they felt towards the crimes committed during the last Argentinian military dictatorship.

\section{Acknowledgements}

I am extremely grateful to Mike Byram for his continuous feedback, to Melina Porto for her unwavering support and to John Manders for his bright suggestions as an intelligent reader. My deepest appreciation goes to all the participating students in this study.

\section{References}

Barboni, S., Beacon, G. \& Porto, M. (2008). Diseño curricular de inglés para educación primaria básica de la Provincia de Buenos Aires. Diseño curricular para la educación primaria. Segundo ciclo. Edición 1, 1 (pp. 321-352). La Plata, Argentina: Dirección de Currículum, Dirección General de Cultura y Educación de la Provincia de Buenos Aires.

Barkan, E. (2000). The guilt of nations: Restitution and negotiating historical injustices. New York: W.W. Norton.

Barnett, R. (1997). Towards a higher education for a new century. University of London, Institute of Education.

Beacon, G., Barboni, S., Porto, M. \& Spoturno, L. (2013). Diseño curricular para la educación primaria. Primer ciclo. Área inglés. Dirección General de Cultura y Educación del Gobierno de la Provincia de Buenos Aires.

Bowers, M. \& Yehuda, R. (2016). Intergenerational Transmission of Stress in Humans. Neuropsychopharmacology Reviews, 41, 232-244;

British Council (2008). Global citizenship in the English language classroom. Retrieved from:

https://www.teachingenglish.org.uk/sites/teacheng/files/GlobalCitizenv2.pdf (January 2017).

British Council. Connecting Classrooms. Retrieved from: https://schoolsonline.britishcouncil.org/about-schools-online/aboutprogrammes/connecting-classrooms (January 2017).

Byram, M. (1997). Teaching and assessing intercultural communicative competence. Clevedon: Multilingual Matters.

Byram, M. (2008). From foreign language education to education for intercultural citizenship: Essays and reflections. Clevedon: Multilingual Matters.

Byram, M. (2010). Linguistic and cultural education for Bildung and citizenship. Modern Language Journal, 94, 318-321. 
Byram, M. (2012). Conceptualizing intercultural (communicative) competence and intercultural citizenship. In J. Jackson (Ed.), Routledge Handbook of Language and Intercultural Communication (pp. 85-97). Abingdon: Routledge.

Byram, M. (2014a). Twenty-five years on - from cultural studies to intercultural citizenship. Language, Culture and Curriculum, 27, 3, 209-225.

Byram, M. (2014b). Competence, interaction and action. Developing intercultural citizenship education in the language classroom and beyond. In X. Dai and G. Chen (Eds.), Intercultural communication competence: Conceptualization and its development in cultural contexts and interactions (pp.190-198). Newcastle/Tyne: Cambridge Scholars Publishing.

Byram, M., Golubeva, I., Hui, H. \& Wagner, M. (2017). From principles to practice in education for intercultural citizenship. Multilingual Matters.

Byram, M. \& Zarate, G. (1994). Definitions, objectives and assessment of socio-cultural competence. Strasbourg, France: Council of Europe.

Cohen, L., Manion, L. \& Morrison, K. (2011). Research methods in education. London: Routledge.

Corbin, J., \& Strauss, A. (2014). Basics of qualitative research: Techniques and procedures for developing grounded theory. Fourth edition. California: Sage.

Council of Europe (2001). Common European Framework of Reference for Languages: Learning, Teaching, Assessment (CEFR). Retrieved from: http://www.coe.int/t/dg4/linguistic/Cadre1_en.asp (January 2017).

Council of Europe (2010a). Charter on Education for Democratic Citizenship and Human Rights Education. Retrieved from: http://www.coe.int/en/web/edc/charteron-education-for-democratic-citizenship-and-human-rights-education (January 2017).

Council of Europe (2010b). White Paper on Intercultural Dialogue 'Living together as equals in dignity'. Retrieved from: http://www.coe.int/t/dg4/intercultural/source/white\%20paper_final_revised_en.pd

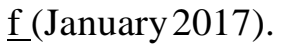

Council of Europe (2016). Competences for democratic culture: Living together as equals in culturally diverse democratic societies. Strasbourg: Council of Europe Publishing.

Dewey, J. (1916). Democracy and education: An introduction to the philosophy of education. New York: Macmillan.

Ehrlich, T. (2000). Civic responsibility and higher education. Phoenix, AZ: Oryx Press.

Enright, R. Rhody, M., Litts, B. \& Klatt, J. (2014). Piloting forgiveness education in a divided community: Comparing electronic pen-pal and journaling activities across two groups of youth. Journal of Moral Education, 43, 1, 1-17.

Ferradas, C. (2008a). Working with values: The value of caring. Ciudad Autónoma de Buenos Aires, Argentina: Pearson Education, S.A.

Ferradas, C. (2008b). Working with values: The value of commitment. Bicentennial campaign. Ciudad Autónoma de Buenos Aires, Argentina: Pearson Education, S.A.

Ferradas, C. (2009). Working with values: The value of diversity. Getting ready for the bicentennial of our nation. Ciudad Autónoma de Buenos Aires, Argentina: Pearson Education, S.A.

Froman, N. (2015). Human rights education and the International Baccalaureate Diploma programme. Current Issues in Comparative Education, 17, 1, 36-58.

Guilherme, M. (2002). Critical citizens for an intercultural world: Foreign language education as cultural politics. Clevedon: Multilingual Matters. 
Guilherme, M. (2007). English as a global language and education for cosmopolitan citizenship. Language and Intercultural Communication, 7, 1, 72-90.

Hatch, A. (2002). Doing qualitative research in education settings. Albany, NY: State University of New York Press.

Hillsborough. (2012). The Report of the Hillsborough Independent Panel. London: The Stationery Office. Retrieved from:

https://www.gov.uk/government/uploads/system/uploads/attachment_data/file/229038/0

581.pdf (January 2017).

Hillyard, S. (2008). English language and the global citizen: Voices from an Argentine classroom. In Global citizenship in the English language classroom, British

Council. Retrieved from:

https://www.teachingenglish.org.uk/sites/teacheng/files/GlobalCitizenv2.pdf (January 2017).

Kemmis, D. (1990). Community and the politics of place. Norman, OK: University of OklahomaPress.

Kreber, C. (2016). Educating for civic-mindedness: Nurturing authentic professional identities through transformative higher education. Oxon: Routledge.

Leen-Feldner, E., Feldner, M., Knapp, A. Bunaciu, L. Blumenthal, H. Amstadter, A. (2013). Offspring psychological and biological correlates of parental posttraumatic stress: Review of the literature and research agenda. Clinical Psychology Review, 33, 8, 1106-1133.

Ministerio de Educación, Argentina (2011). Secretaría de Políticas Universitarias. Instituto Nacional de Formación Docente. Proyecto de mejora para la formación inicial de profesores para el nivel secundario: Âreas: Geografía, Historia, Lengua

y Literatura y Lenguas Extranjeras. Ministerio de Educación.

Retrieved from: http://cedoc.infd.edu.ar/upload/lenguas_extranjeras.pdf (January 2017).

Osborn, T. (2006). Teaching world languages for social justice: A sourcebook of principles and practices. London: Routledge.

Osler, A. (2012). Citizenship education and diversity. In J.A. Banks (Ed.), Encyclopedia of Diversity in Education (Vol. 1) (pp. 353-361). Los Angeles, CA: Sage.

Osler, A., \& Starkey, H. (Eds.). (2005). Citizenship and language learning: Internationalperspectives. Stoke-on-Trent:Trentham Books.

Osler, A. \& Starkey, H. (2015). Education for cosmopolitan citizenship: A framework for language learning. Argentinian Journal of Applied Linguistics, 3, 2, 30-39.

Oxfam (1997) A curriculum for global citizenship. Oxford, UK: Oxfam.

Porto, M. (2014). Intercultural citizenship education in an EFL online project in Argentina. Language and Intercultural Communication, 14, 2, 245-261.

Porto, M. (2015). Special issue of Argentinian Journal of Applied Linguistics, 3, 2.

Porto, M. \& Byram, M. (2015). A curriculum for action in the community and intercultural citizenship in higher education. Language, Culture and Curriculum, $28,3,226-242$.

Shechtman, Z., Wade, N., \& Khoury, A. (2009). Effectiveness of a forgiveness program for Arab Israeli adolescents in Israel: An empirical trial. Peace and Conflict Studies, 15, 415-438.

Siderac, S. \& Paez, A.C. (2013). Hacia la autonomía y la construcción crítica de la ciudadanía: Una experiencia en Santa Rosa, La Pampa. Anuario de la Facultad de Ciencias Humanas, 10, 2, 1-12.

Starkey, H. (2011). Citizenship, education and global spaces. Language and Intercultural Communication, 11, 2, 75-79. 
Struthers, A.E.C. (2015) Human rights education: educating about, through and for human rights. The International Journal of Human Rights, 19, 1, 53-73.

Taylor, K.B. (2005). A gathering of great minds: Designing twenty-first century education with twentieth century ideas. About Campus, 10, 2, 17-23.

UN General Assembly, United Nations Declaration on Human Rights Education and Training (2011). Resolution A/RES/66/137, Articles 1 to 14. Retrieved from: http://www.ohchr.org/EN/Issues/Education/Training/Pages/UNDHREducationTra ining.aspx (January 2017).

White, M. (2013). Higher education and problems of citizenship formation. Journal of Philosophy of Education, 47, 1, 112-127.

Yehuda, R., Daskalakis, N., Bierer, L., Bader, H., Klengel, T., Holsboer, F., \& Binder, E. (2016) Archival Report: Holocaust Exposure Induced Intergenerational Effects on FKBP5 Methylation. Corticotropin-Releasing Factor, FKBP5, and Posttraumatic Stress Disorder, Biological Psychiatry, 80, 5, 372-380.

Yulita, L. \& Porto, M. (2017). Human rights education in language teaching. In M. Byram, I. Golubeva, H. Hui \& M. Wagner (Eds.), From principles to practice in education for intercultural citizenship (pp. 225-250). Multilingual Matters. 